\title{
Introduction: From Switzerland to the Indies
}

\author{
Simona Boscani Leoni, Sarah Baumgartner and Meike Knittel
}

In Zurich, in the early 18th century, the physician and naturalist Johann Jakob Scheuchzer (1672-1733) published a bibliography of all books on natural history that he knew about. His catalogue contained publications on Europe, Africa, Asia, and the Americas. Scheuchzer's idea was to bring together the different local natural histories into a natural history of the world. His own contribution to this "global natural history" was his research on the Alps and its fauna, flora, minerals and about "homo alpinus helveticus" ("Swiss Alpine Man"). ${ }^{1}$

Half a century later, the Physical Society of Zurich, a patriotic society interested in natural sciences and agronomy, inspired by similar projects undertaken by other economic societies, conducted surveys of the city's subject territory. ${ }^{2}$ Likewise, animated by reports on travels to hitherto unknown regions and news about the exploration of faraway territories, diverse actors - both academically and non-academically educated - all over Europe became increasingly interested in their surroundings. Drawing on travelogues and questionnaires of local and colonial actors as well as on their own observations, early modern natural historians collected information about both nature and people inhabiting these territories, which helped to turn them into distinct spaces. ${ }^{3}$

1 Johann Jakob Scheuchzer, Bibliotheca scriptorum historiae naturalis omnium Terrae Regionum inservientium; historiae naturalis Helvetiae Prodromus; accessit Celeberrimi Viri Jacobi Le Long, Bibliothecarii Oratoriani de Scriptoribus historiae naturalis Galliae; collegit Johann Jakob Scheuchzer, Med. D. Math. Prof. Societ. Leopoldino-Carolinae, Regiae Angl. \& Boruss. (Tiguri: Typis Henrici Bodmeri, 1716). About Johann Jakob Scheuchzer, see: Simona Boscani Leoni, ed., Wissenschaft - Berge - Ideologien: Johann Jakob Scheuchzer (1672-1733) und die frühneuzeitliche Naturforschung - Scienza - montagna - ideologie. Johann Jakob Scheuchzer (1672-1733) e la ricerca naturalistica in epoca moderna (Basel: Schwabe, 2010); Urs B. Leu, ed., Natura Sacra: Der Frühaufklärer Johann Jakob Scheuchzer (1672-1733) (Zug: Achius Verlag, 2012); Michael Kempe, Wissenschaft, Theologie, Aufklärung: Johann Jakob Scheuchzer (16721733) und die Sintfluttheorie (Epfendorf: bibliotheca academica Verlag, 2003).

2 Sarah Baumgartner, "Das nützliche Wissen. Akteure, Tätigkeiten, Kommunikationspraxis und Themen der Naturforschenden Gesellschaft in Zürich, 1746 bis ca. 183o" (PhD diss., Universitity of Bern, 2019); Rolf Graber, Bürgerliche Öffentlichkeit und spätabsolutistischer Staat: Sozietätenbewegung und Konfliktkonjunktur in Zürich 1746-1780 (Zurich: Chronos, 1993).

3 On travels, queries and instructions for travellers: Maurizio Bossi and Claudio Greppi, eds., Viaggi e scienza: le istruzioni scientifiche per i viaggiatori nei secoli XVII-XIX, Gabinetto scientifico letterario G. P. Vieusseux, Studi 13 (Florence: Olschki, 2005); Lorelai Kury, "Les 


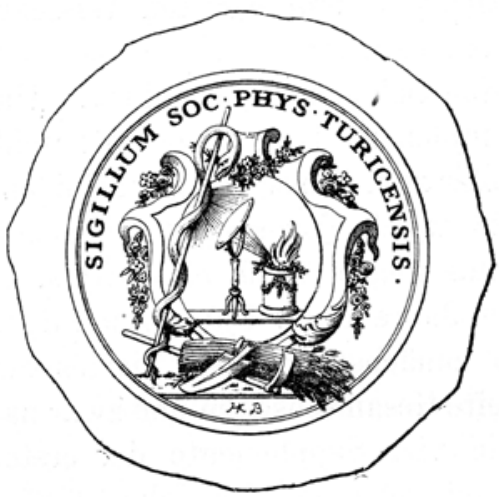

FIGURE 1.1

Seal of the Physical Society Zurich (Physikalische Gesellschaft Zürich or Naturforschende Gesellschaft Zürich)

SOURCE: FERDINAND RUDIO, FESTSCHRIFT DER NATURFORSCHENDEN GESELLSCHAFT IN ZÜRICH, 1746-1896, ZURICH, IN KOMMISSION BEI FÄSI \& BEER, 1896, 213

Since the early days of European presence in the Americas, information reaching Europe contributed to a critical re-reading of Aristotle and other classical texts: Renaissance scholars shared the view that the natural world was still largely unknown and that many secrets were waiting to be investigated. ${ }^{4}$ Curiosity revived, not only for antiquities, but for "exotic" and local nature, especially for "exotic" and local flora and fauna, and for minerals, more particularly for local characteristics of the terrain, orology and hydrology. Civil and natural history, geography and antiquarianism are very long-standing "travelling companions" in the early modern age.

instructions de voyage dans les expéditions scientifiques françaises (1750-1830)," Revue d'histoire des sciences 51, no. 1 (1998); Justin Stagl, A History of Curiosity: The Theory of Travel 1550-180o (Chur: Harwood Academic Publishers, 1995); Daniel Carey, "Inquiries, Heads, and Directions: Orienting Early Modern Travel," in Travel Narratives, the New Science and Literary Discourse: 1569-1750, ed. Judy A. Hayden (Farnham: Ashgate, 2012); Lorelai Kury, Histoire naturelle et voyages scientifiques (1780-1830) (Paris: L'Harmattan, 2001); Joan-Pau Rubiés, "Instructions for Travellers: Teaching the Eye to See," History and Anthropology 9, no. 2-3 (1996); Alix Cooper, "Fragen ohne Antworten: Die Suche nach lokalen Informationen in der frühen Aufklärung," in Vor Google: Eine Mediengeschichte der Suchmaschine im analogen Zeitalter, ed. Thomas Brandstetter (Bielefeld: transcript, 2012).

4 On the complexity of natural history during the Renaissance, the "discovery" of the Americas and the development of a colonial botany, see: Brian W. Ogilvie, The Science of Describing: Natural History in Renaissance Europe (Chicago, London: The University of Chicago Press, 2006); Londa Schiebinger and Claudia Swan, eds., Colonial Botany: Science, Commerce, and Politics in the Early Modern World (Philadelphia: University of Pennsylvania Press, 2005); Samir Boumediene, La colonisation du savoir: une histoire des plantes médicinales du "Nouveau Monde" (1492-1750) (Vaulx-en-Velin: Les éditions des mondes à faire, 2016); Norbert Ortmayr, "Kulturpflanzentransfers 1492-1900," Historische Sozialkunde: Geschichte, Fachdidaktik, politische Bildung 1 (2002); Yota Batsaki, Sarah Burke Cahalan and Anatole Tchikine, eds., The Botany of Empire in the Long Eighteenth Century (Washington, DC: Dumbarton Oaks Research Library and Collection, 2016). 
The final decades of the 18th century became a crucial period for the different fields of natural history and related disciplines of ethnology and archaeology, as academic subjects in light of the advancement of Linnaean systematic classification in botany and zoology. ${ }^{5}$ The perception and systematization of the natural world went through a paradigmatic shift as a result. Collections and the practice of collecting itself played a major role in this process and influenced the global exchange of ideas, knowledge, specimens, and personnel. Material as well as intellectual exchange took place in diverse settings, including collections, media, lecture halls, and the natural world itself.

This publication brings together several researchers from around the globe, who have analysed the exploration of the different "local natures" (natural history) and the discovery of "local inhabitants and their history" (ethnography and antiquarianism) from a comparative perspective in the long 18 th century. ${ }^{6}$ The focus on this period, a time when scientific travels and expeditions around the world increased, is especially fruitful inasmuch as it re-visits debates on the periodization of this "discovery of the indigenous". ${ }^{7}$ The articles collected here cast a transnational look at European science, at home and abroad, as well as at scientific practice globally, and at the involvement of a great variety of local actors, for example academies and learned societies. This comparative and longue durée approach is supported by the ability to transcend individual disciplines and to combine the histories of natural history, medicine, environmental history, ethnology and archaeology as well as their interconnections. Finally, the book questions the different contexts of knowledge creation, be they political (republics, monarchies, colonial rule, etc.), material or linguistic. Based on the findings of historians, with particular emphasis on the social and cultural practices of early-modern natural history, the book focuses especially on collecting and exchanging, measuring and classifying information on territories of different scope.

5 Lisbet Koerner, Linnaeus: Nature and Nation, 3rd ed. (Cambridge, MA: Harvard University Press, 2001).

6 The book was inspired by discussions and reflections developed during an international conference organized at the University of Bern by the editors of the volume in collaboration with the Lichtenberg-Kolleg of the Georg-August-University, Göttingen (Dominik Hünniger) under the title of "Mapping the Territory: Exploring People and Nature, 1700 until 1830" (21-23 September 2017). The conference was financed by the Swiss National Science Foundation (Project no. 174561), the University of Bern, the Centre for Global Studies of the University of Bern, the Swiss Academy of Humanities and Social Sciences, the Burgergemeinde Bern, and the Swiss Society for Eighteenth-Century Studies. The editors thank all speakers for their active participation in the success of the conference.

7 Alix Cooper, Inventing the Indigenous: Local Knowledge and Natural History in Early Modern Europe (Cambridge: Cambridge University Press, 2007). 
Four main questions inspired this publication. ${ }^{8}$ The first one concerns the actors of natural history. Over the last decades, the attention of historians has shifted from individual figures, more exactly learned men with an academic training, like physicians and professors, to the diverse actors doing natural history, i.e. amateurs (or grassroots), practitioners, family members, and women. ${ }^{9}$ Through the proliferation of communication channels in the early modern age, university-trained scholars were able to establish contact with people of different social backgrounds, with or without academic training, with merchants, diplomats, (court and colonial) officials, clergymen (pastors of the Protestant and Reformed Church, priests or Jesuits) as well as with artisans, apothecaries, gardeners, hunters, and peasants..$^{10}$ Not only were the networks socially diverse, but they also ranged from local to global networks of research in people, fauna and flora. ${ }^{11}$

The book is linked to a Swiss National Science Foundation-sponsored Professorship project led by Simona Boscani Leoni (Project no.: 144731), which ran from 2013 (October) to 2017 (September) under the title: "Cultures of Natural History: Main Actors, Networks and Places of Scientific Communication in the Early-Modern Period". Sarah Baumgartner and Meike Knittel participated in the project as scientific collaborators and wrote their $\mathrm{PhD}$ dissertations during the period. Baumgartner, "Das nützliche Wissen”; Meike Knittel, "Netzwerke der Botanik. Johannes Gessner (1709-179o) und die botanische Forschung im 18. Jahrhundert" (PhD diss., University of Bern, 2018). An extension of the project under the title: "Cultures of natural history online. Main actors, networks, topics in the longue durée (1550 to around 1830)" is still continuing at the University of Bern (Project no.: 176978).

9 A pioneer work on women in the sciences was: Londa Schiebinger, The Mind has no Sex? Women in the Origins of Modern Science (Cambridge, MA: Harvard University Press, 1989).

10 About these (in)visible assistants/helpers: Steven Shapin, "The Invisible Technician," AmericanScientist77, no.6(1989);IwanR.Morus, "InvisibleTechnicians, Instrument-Makers and Artisans," in A Companion to the History of Science, ed. Bernard V. Lightman (New York: John Wiley and Sons, 2016); Dunja Bulinsky, Nahbeziehungen eines europäischen Gelehrten:Johann Jakob Scheuchzer (1672-1733) und sein soziales Umfeld (Zurich: Chronos Verlag, 2020); Sophie Ruppel, Botanophilie: Mensch und Pflanze in der aufklärerischbürgerlichen Gesellschaft um 1800 (Vienna: Böhlau, 2019); Monika Mommertz, "Heroization in Science, Scholarship, and Knowledge-Production: The Intellectual Hero in Transdisciplinary and Trans-Epochal Perspective," Helden. Heroes. Héros. Special Issue 4 (2018); Simona Boscani Leoni, ed., "Unglaubliche Bergwunder": Johann Jakob Scheuchzer und Graubünden. Ausgewählte Briefe 1699-1707 (Chur: Verlag Bündner Monatsblatt, 2019); Valentina Pugliano, "Natural History in the Apothecary's Shop," in Worlds of Natural History, ed. Helen A. Curry, Nicholas Jardine, James A. Secord, and Emma C. Spary (Cambridge: Cambridge University Press, 2018) and the special issue of Berichte zur Wissenschaftsgeschichte 44, no. 2 (2021): Working at the Margins: Labor and the Politics of Participation in Natural History, 1700-1830, ed. Patrick Anthony.

11 For this communicative network of naturalists/botanists, see for example: Bettina Dietz, Das System der Natur: Die kollaborative Wissenskultur der Botanik im 18. Jahrhundert 
The second question focuses on the role of communication networks and their spread across local, transregional and global levels, beyond confessional and class differences. Thirdly, we wanted to examine the research practices of the different actors involved in "natural knowledge production" and their fieldworks. Finally, our fourth prompt was the definition of the different lieux de savoir and their function in this context. ${ }^{12}$ By lieux de savoir we mean different spaces where practical-empirical knowledge was produced and exchanged, especially anatomy theatres, botanical gardens, natural history and antiquarian collections, but also academies or economic and patriotic societies. ${ }^{13}$

Considering these multiple networks, research practices and lieux de savoir, which enabled naturalists to collect and process natural history data and information during the early modern period, we can say that research in these fields was actually polyphonic and multifarious: a combination of different "cultures of natural history", learned as well as popular. ${ }^{14}$ They came into contact through different research practices, such as questionnaires, and findings were eventually published in scholarly publications. ${ }^{15}$ We can provide evidence of knowledge making as a multi-layered, non-linear process, a collective enterprise that

(Cologne: Böhlau, 2017); Regina Dauser et al., eds., Wissen im Netz: Botanik und Pflanzentransfer in europäischen Korrespondenznetzen des 18. Jahrhunderts (Berlin: AkademieVerlag, 2008). For an example of local/transregional correspondence: Boscani Leoni, "Unglaubliche Bergwunder".

12 Arthur MacGregor, ed., Naturalists in the Field: Collecting, Recording and Preserving the Natural World from the Fifteenth to the Twenty-First Century (Leiden: Brill, 2018).

13 On global scientific practices between $175^{\circ}$ and 1850: Patrick Manning and Daniel Rood, Global Scientific Practice in an Age of Revolutions, 1750-1850 (Pittsburgh: University of Pittsburgh Press, 2016). For the concept of lieu de savoir: Christian Jacob, ed., Lieux de savoir: espaces et communautés (Paris: Albin Michel, 2007); Paula Findlen, "Anatomy Theaters, Botanical Gardens, and Natural History Collections," in The Cambridge History of Science: Early Modern Science, ed. Katharine Park and Lorraine Daston (Cambridge: Cambridge University Press, 2006); René Sigrist, Eric Widmer, and Wladimir Berelowitsch, "Les lieux des sciences dans l'Europe moderne," in Lieux d'Europe: mythes et limites, ed. Stella Ghervas and François Rosset (Paris: Ed. de la Maison des sciences de l'homme, 2008). See also: Bruno Latour, Science in Action: How to Follow Scientists and Engineers Through Society (Cambridge, MA: Harvard University Press, 1987).

14 For pioneer work on these topics, see: Nicholas Jardine, Emma Spary, and James A. Secord, eds., Cultures of Natural History (Cambridge: Cambridge University Press, 1996); Nicholas Jardine and Emma Spary, "Worlds of History," in Curry, Jardine, Secord, Spary, Worlds of Natural History.

15 Simona Boscani Leoni, "Queries and Questionnaires: Collecting Local and Popular Knowledge in 17th and 18th Century Europe," in Wissenschaftsgeschichte und Geschichte des Wissens im Dialog - Connecting Science and Knowledge, ed. Kaspar von Greyerz, Silvia Flubacher, and Philipp Senn (Göttingen: V\&R unipress, 2013). 
involved diverse institutions and actors. The notion of "nature" emerged from different projections and ideals.

Some topics we have been scrutinising during the last few years offer further entry points from which to reach a clearer understanding of the collaborative culture of naturalists worldwide in the long 18th century: in particular, the investigation of the role of botanical networks and of economic societies in the discussion and dissemination of natural knowledge. Looking at different types of sources, such as letters, plant lists and printed botanical works by different actors (naturalists, but also state officials, merchants, and priests), we have been examining the ways in which books, plants, and seeds circulated from one continent to another, between big cities, capitals, small towns and more isolated places, for example in mountain regions. From these sources we understand that the geography of knowledge was relative and complex indeed. It encompassed hub cities - which housed universities and a plethora of other lieux de savoir and were directly connected to Atlantic ports -, peripheral towns and villages on a global scale and the problem of acceptance of other (i.e. non-European) forms of knowledge (see Stefanie Gänger's contribution in this volume). ${ }^{16}$ In that respect, we have to consider the existence of different levels in the relationship between centres of knowledge production and so-called "peripheries." The exchange of Alpine plants, for example, and the special therapeutic qualities credited to Alpine air, milk and plants shows that there was something exceptional about these supposedly barren regions in Europe. Their exceptionality, combined with the limited knowledge of their "wild" nature, turns them into a sort of intra-European counterpart to non-European exoticism, as well as other peripheral regions (for more on this, see Meike Knittel's, Simona Boscani Leoni's, Barbara Orland's and Stefanie Gänger's articles in this volume). ${ }^{17}$

16 On this topic: Kenneth Pomeranz, The Great Divergence: China, Europe, and the Making of the Modern World Economy (Princeton: Princeton University Press, 20oo); Marie-Noëlle Bourguet, "Voyages lointains et mesure du monde: la projection du regard européen sur le monde (vers 150o-vers 180o)," in L'Europe des sciences et des techniques XV ${ }^{e}-X V I I I^{e}$ siècles: un dialogue des savoirs, ed. Liliane Hilaire-Pérez, Fabien Simon, and Marie Thébaud-Sorger (Rennes: Presses universitaires de Rennes, 2016); Bruno Latour, "Comment redistribuer le Grand Partage?," Revue de synthèse 110 (1983); Latour, "Visualisation and Cognition: Drawing Things Together," in Knowledge and Society: Studies in the Sociology of Culture Past and Present, vol. 6, ed. Henrika Kuklick and Elizabeth Long (Greenwich, CT: Jai Press, 1986), 6.

17 On the "exotic Alps": Bernhard C. Schär, "On the Tropical Origins of the Alps: Science and the Colonial Imagination of Switzerland, 1700-1900," in Colonial Switzerland: Rethinking Colonialism from the Margins, eds. Patricia Purtschert and Harald Fischer-Tiné (Basingstoke: Palgrave Macmillan, 2015); Simona Boscani Leoni, "The Discovery of the Alps: 
Regarding the development of botanical and agronomic studies during the 18th century, it is worth mentioning the rise of economic-patriotic societies, which conducted surveys on territories (Sarah Baumgartner, Martin Stuber). ${ }^{18}$ These institutions were very important local actors in the process of mapping territories: they were interested in conducting the most precise surveys possible of the agricultural, economic and human resources of a region, trying - somewhat paternalistically - to involve peasants in the process of "optimisation" of agriculture. ${ }^{19}$ In this context, too, the reception and circulation of knowledge must be considered as an active process, strongly dependent on the particular circumstances and on the interests of the actors involved. ${ }^{20}$ Measuring territories cartographically and cataloguing the flora, fauna, and minerals of an area also influenced (and still does) the perception of the

Between 'Science' and Exoticism," in Exotic Switzerland? Looking Outward in the Age of Enlightenment, ed. Noémie Etienne, Claire Brizon, Chonja Lee, and Etienne Wismer (Berlin: Diaphanes, 2020). For other remote regions and 18th century natural history, see e.g.: Linda Andersson Burnett, "An Eighteenth-Century Ecology of Knowledge: Patronage and Natural History," Culture Unbound - Journal of Current Cultural Research 6 (2014).

18 For example: Koen Stapelbroek and Jani Marjanen, eds., The Rise of Economic Societies in the Eighteenth Century: Patriotic Reform in Europe and North America (Basingstoke: Palgrave Macmillan, 2012); see also: Alix Cooper, "The 'Possibilities of the Land': The Inventory of 'Natural Riches' in the Early Modern Territories," in Oeconomies in the Age of Newton, eds. Margaret Schabas and Neil de Marchi (Durham, NC: Duke University Press, 2003).

19 OntheEconomicEnlightenmentandits "culture of innovation"(Innovationskultur):Marcus Popplow, "Die Ökonomische Aufklärung als Innovationskultur des 18. Jahrhunderts zur optimierten Nutzung natürlicher Ressourcen," in Landschaften agrarisch-ökonomischen Wissens: Strategien innovativer Ressourcennutzung in Zeitschriften und Sozietäten des 18. Jahrhunderts, ed. Marcus Popplow (Münster: Waxmann, 2010).

20 On the concepts of transfer/circulation of knowledge, for example: Claire Gantet and Markus Meumann, eds., Les échanges savants franco-allemands au XVIII e siècle: transferts, circulations et réseaux (Rennes: Presses universitaires de Rennes, 2019); Mitchell G. Ash, "Wissens- und Wissenschaftstransfer - einführende Bemerkungen," Berichte zur Wissenschaftsgeschichte 29, no. 3 (2006); Silvia Capanema, Quentin Deluermoz, Michel Molin, and Marie Redon, eds., Du transfert culturel au métissage: concepts, acteurs, pratiques (Rennes: Presses universitaires de Rennes, 2015); Thomas DaCosta Kaufmann, "Interpreting Cultural Transfer and the Consequences of Markets and Exchange: Reconsidering Fumi-E," in Artistic and Cultural Exchanges Between Europe and Asia, 1400-1900: Rethinking Markets, Workshops and Collections, ed. Michael North (London: Routledge, 2010); Michel Espagne, "Der theoretische Stand der Kulturtransferforschung," in Kulturtransfer: Kulturelle Praxis im 16. Jahrhundert, ed. Wolfgang Schmale (Innsbruck: StudienVerlag, 2003); Ortmayr, "Kulturpflanzentransfers 1492-190o". 
different regions; in other words, such undertakings are an important component of "making landscapes." ${ }^{21}$

Natural history was at once "local" and "global." As we pointed out at the beginning of this Introduction, in 1716 Johann Jakob Scheuchzer published a bibliography of all books on natural history from the Renaissance to the 18th century, under the title of Bibliotheca scriptorum historiae naturalis omnium Terrae Regionum inservientium. ${ }^{22}$

His idea was to assemble the different "local" natural histories into a natural history of the world. To explain the intentions of his enterprise, he wrote in the Preface to his Bibliotheca scriptorum:

I know that the natural history of a territory is related to the natural history of many others, which are sometimes very remote. We cannot investigate one territory without knowing the other ones. I sometimes needed to look for Switzerland in the Indies and for the Indies in Switzerland. ${ }^{23}$

The Bibliotheca scriptorum shows how Scheuchzer interpreted the natural history of Switzerland (and its "wild" landscapes, the Alps) from the perspective of an increased presence of Europeans in non-Europeans areas and in terms of a discovery of the "exotic."24 In the chapter devoted to the Americas, Scheuchzer not only highlighted the vastness of the country and the fertility of the lands, but he also mentioned about forty authors of naturalistic texts devoted to the New Continent. ${ }^{25}$ These included Johannes Fragoso, a Toledo doctor at the

21 We subscribe to W. J. Thomas Mitchell's definition of landscapes "as a process by which social and subjective identities are formed," W. J. Thomas Mitchell, "Introduction," in Landscape and Power, ed. W. J. Thomas Mitchell, 2nd ed. (Chicago, London:The University of Chicago Press, 2002), 1; Daniel Speich, "Mountains Made in Switzerland: Facts and Concerns in Nineteenth-Century Cartography," Science in Context 22, no. 3 (2009).

22 Scheuchzer, Bibliotheca scriptorum historiae naturalis omnium Terrae Regionum inservientium; historiae naturalis Helvetiae Prodromus; accessit celeberrimi viri Jacobi Le Long, Bibliothecarii Oratoriani de Scriptoribus historiae naturalis Galliae; collegit Johann Jakob Scheuchzer, Med. D. Math. Prof. Societ. Leopoldino-Carolinae, Regiae Angl. \& Boruss.

23 Original: "Ita, nosti, innexa est unius Regionis Historia Naturalis cum aliorum, longissimè etiam dissitarum, Historia, ut vix unam plenè elaborare possis sine alia [...]. Helvetiam haud rarò quaerere necesse habeo in Indiis; et Indiam in Helvetia," ibid., Praefatio ad lectorem (unpaginated).

24 This form of thought is at the basis of the development of colonial thought in the 18th century. On the topic: Bernhard C. Schär, "Bauern und Hirten reconsidered: Umrisse der 'erfundenen Schweiz' im imperialen Raum," in Postkoloniale Schweiz: Formen und Folgen eines Kolonialismus ohne Kolonien, ed. Patricia Purtschert (Bielefeld: transcript, 2012).

25 Scheuchzer, Bibliotheca scriptorum historiae naturalis omnium Terrae Regionum inservientium; historiae naturalis Helvetiae Prodromus; accessit celeberrimi viri Jacobi Le Long, 


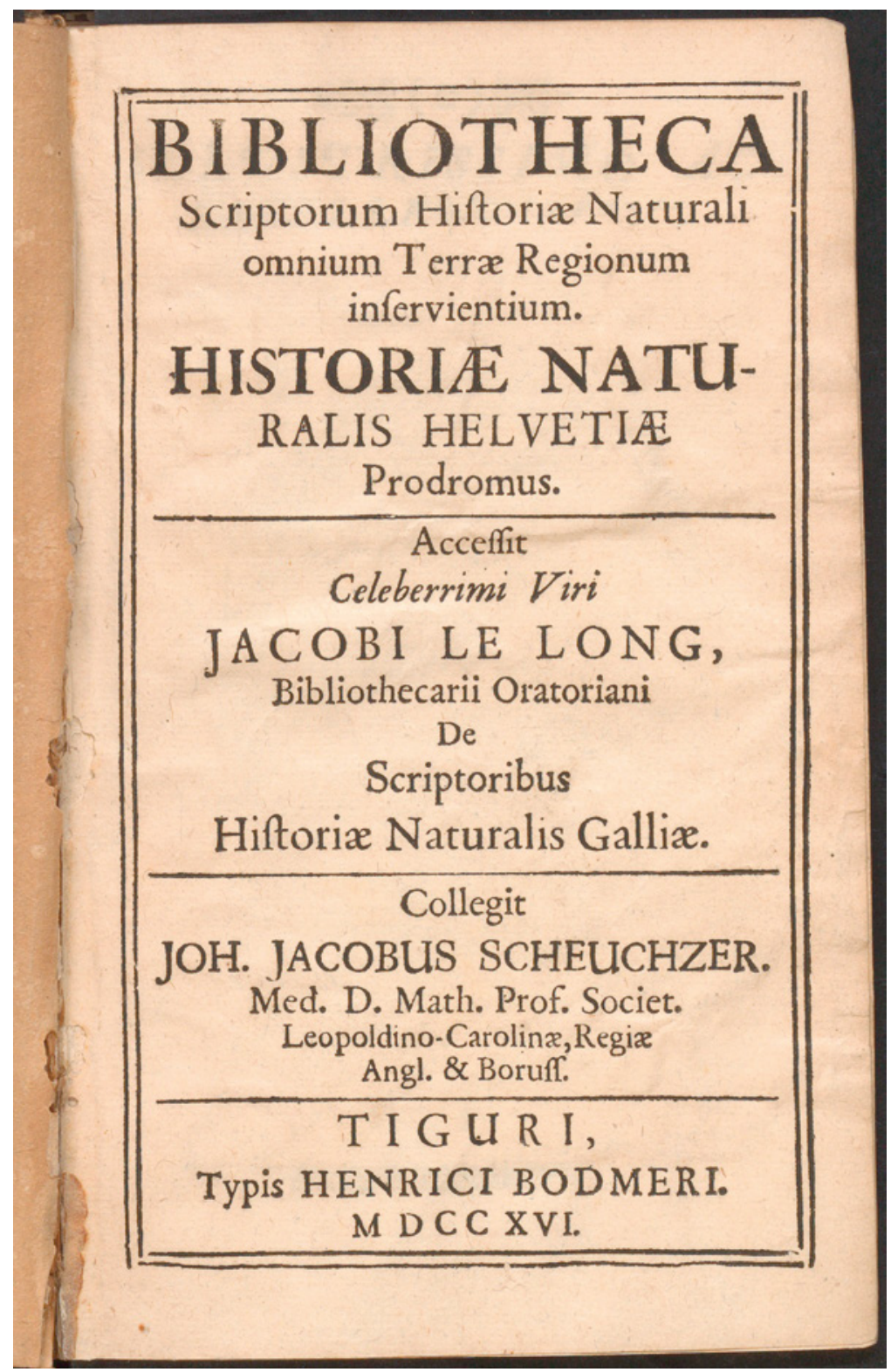

FIGURE 1.2 Frontispiece of Johann Jakob Scheuchzer, Bibliotheca scriptorum historiae naturalis omnium Terrae Regionum inservientium; historiae naturalis Helvetiae Prodromus; accessit Celeberrimi Viri Jacobi Le Long, Bibliothecarii Oratoriani de Scriptoribus historiae naturalis Galliae; collegit Johann Jakob Scheuchzer, Med. D. Math. Prof. Societ. LeopoldinoCarolinae, Regiae Angl. \& Boruss. (Tiguri: typis Henrici Bodmeri, 1716). ETH-Bibliothek Zurich, Shelf mark: Rar 10537 
court of Philip II, Francisco Hernández (in the 1651 edition), Nardo Antonio Recchi, Francisco Ximenez, and Nicolás Monardes (also cited in Scheuchzer's chapter on Asia) together with the Inca Garcilaso de la Vega. These observations about the Bibliotheca scriptorum are noteworthy because they underline once more a central topic of this book, i.e. the linkage between local and global natural history, as well as the importance of the American and Asian territories for an inventory of the natural history of the world (one that included human beings). ${ }^{26}$

The contributions assembled in this volume examine from a comparative perspective the exploration of the different "local natures" and the discovery of "local inhabitants and their history" in a period marked by an increase in scientific travels and expeditions around the world. They give crucial impetus to the debate on the periodization of this "discovery of the indigenous," and the different stages of this development, while bringing to light the social and cultural practices of natural history, the media, methods and tools used to collect, classify and communicate information on territories. ${ }^{27}$ Through four chapters dealing with Switzerland the book also insists on the entanglement of local and global networks of natural and civil history in the modern age, placing the Old Confederacy, a landlocked territory with no colonies, within the developments of global knowledge (but also global trade). To return to Scheuchzer's quotation about the Indies in Switzerland and Switzerland in the Indies, this shows well the deep connections, of which the naturalists themselves were aware, during the European colonisation of the Americas and the import of

Bibliothecarii Oratoriani de Scriptoribus historiae naturalis Galliae; collegit Johann Jakob Scheuchzer, Med. D. Math. Prof. Societ. Leopoldino-Carolinae, Regiae Angl. \& Boruss., Dedicatio (unpaginated), 184, 201, 211.

26 For a discussion on the development of forms of empirical research in the 16th century during the construction of the Spanish colonial empire in the Americas: Antonio Barrera-Osorio, Experiencing Nature: The Spanish American Empire and the Early Scientific Revolution (Austin: University of Texas Press, 2006); Kapil Raj, "Quand l'Amérique a inventé la science européenne," in Europa: une autre histoire, ed. Jakob Vogel, Thomas Serrier and Etienne François (Paris: Les Arènes, 2017); Raj, "Thinking Without the Scientific Revolution: Global Interactions and the Construction of Knowledge," Journal of Early Modern History 21 (2017); Eve Darian-Smith and Philip C. McCarty, eds., The Global Turn: Theories, Research Designs, and Methods for Global Studies (Oakland: University of California Press, 2017); Sebastian Conrad, What Is Global History? (Princeton: Princeton University Press, 2016); Romain Bertrand, "Histoire globale, histoires connectées. Un 'tournant' historiographique?," in Le tournant global des sciences sociales, ed. Alain Caillé and Stéphane Dufoix (Paris: Ed. La Découverte, 2013); Fa-ti Fan, "The Global Turn in the History of Science," East Asian Science, Technology and Society: An International Journal 6 (2012).

Cooper, Inventing the Indigenous. 
new products from the West Indies as substitutes for products from the East Indies. The very definition of the quality of Swiss, respectively Alpine nature (i.e. Alpine products) must be read not only as a "discovery of indigenous nature," but also as an attempt to exploit on the market of knowledge (and new commercial products) plants, animals and minerals that could have had a therapeutic and commercial use. In this way, Scheuchzer and other Swiss naturalists like him, linked this Central European confederation of republican citystates to the global networks and placed the "Swiss/Alpine wonders" within the competition between the Atlantic World and Asia. ${ }^{28}$

The book is organised in three sections. Section I, entitled Naturalists' Methods, concentrates on different aspects and methods of mapping a territory. In what ways was new knowledge of people and nature achieved based on data collected from travel and empirical research? Who were the actors involved? Who and what were the people and objects studied? What territories were surveyed and why? The first contribution (Simona Boscani Leoni) analyses the improvement of questionnaires for gathering information on people, on natural history and resources in the construction of colonial empires in early modern Europe (Spain and Britain), the relationship between knowledge and power, and the development of this empirical method to explore Europe's "wild" regions (the Alps and the Apennines). In the second contribution, Francesco Luzzini sheds light on the efforts of naturalists to define a systematic approach to investigations of nature and people at the beginning of the 18th century. His source is a recently rediscovered manuscript reporting the first scientific journey across the Apennines by the geologist Antonio Vallisneri (1661-1730). Luzzini shows how the Italian naturalist made ground-breaking contributions to many crucial issues in the history of early modern science. Vallisneri was also interested in the local communities and in the study of their relationship with the environment. Both papers (Boscani Leoni's and Luzzini's) consider different ways of mapping local nature and people (the resources of a country), collecting local knowledge ("local lore") and the role of the "inhabitants" in this context (whether Native Americans or European mountaineers).

The third paper of the section seeks to understand how an observer's perception of plants varies when they grow near or far away from them. Meike Knittel, in fact, examines how prints as well as specimens inspired and framed

28 Johann Jakob Scheuchzer entitled his questionnaire dedicated to collecting information on Swiss natural history Letter of invitation to explore the natural wonders to be found in the Swiss countryside: Johann Jakob Scheuchzer, Einladungs-Brief, zu Erforschung natürlicher Wunderen, so sich im Schweizer-Land befinden (Zürich: [D. Gessner], 1699), edited in Boscani Leoni, "Unglaubliche Bergwunder", 35-49. 
European naturalists' engagement with plants from different territories. The topos of the "secretive Indian knower" stands at the heart of Stefanie Gänger's contribution. Examining the development of this epistemic category until the Enlightenment, Gänger explores the role of the figure in the dynamic relationship between European and Creole science and its similarities with other "illiterate," "experiential," and "inscrutable" knowers such as European peasants and women.

Section II considers the Authorities' and Societies' Strategies in mapping procedures. The first paper of this section, by Irina Podgorny, examines the system of production and circulation of knowledge between Spanish America and Europe, and its links to bureaucracy and to Atlantic trade in the years between the end of the 18th and the beginning of the 19th century. Podgorny convincingly points out not only the continuity in the research practices after Spanish America's Revolution and Independence, but equally the importance of the circulation of products from the Indies, and the movements of experts frequently dispatched to these regions. Both observations signal the complexity and the long-term dimension of the history of knowledge in the Spanish and American world. This aspect was for a long time overlooked in the narrative of the history of science, which tended to emphasize or privilege the Protestant contribution to science by colonial powers, such as the Netherlands and Britain.

The bureaucratic roots of natural history research in the Americas find their counterpart in the mapping strategies developed during the second half of the 18 th century especially by patriotic or economic societies. Supported by rulers driven by a growing interest in the use and benefits of knowing the natural resources of their subject territories, these societies took the initiative to survey different territories. In this context, the Physical Society of Zurich and the Economic Society of Bern offer two examples of the survey methods of the Economic Enlightenment. Sarah Baumgartner's paper analyses the first demographic surveys in the regional territory of Zurich. The author underlines the multifaceted solutions implemented by several members of the Economic Commission of the Physical Society to improve this kind of investigations. Their approaches mixed influences from different theoretical schools of statistical thought and combined innovative methods in a way that today would be seen to challenge a long-established system of people categorisation. In his contribution, Martin Stuber analyses these aspects in depth, showing how the Economic Society of Bern, through its investigations of the traditional uses of wetlands, developed a form of social anthropology avant la lettre. According to Stuber's thesis, the record of traditional economic practices not only was the prerogative of extra-European expeditions, but it was also widely practised 
in the context of the Economic Enlightenment in Europe ("Ökonomische Aufklärung").

Jon Mathieu's paper introduces the third and last section of the book: Defining Territories. The three articles focus on the definition and perception of mountain and desert landscapes from a global perspective (Mathieu, Orland, and Singh). On the basis of Alexander von Humboldt's Views of Nature in its different editions (from 1808 to 1849), Jon Mathieu analyses the historical perception of two major ecosystems - deserts and mountains - in the period between $175^{\circ}$ and 185 o. Through Humboldt's work one can observe the emergence of a negative perception of the desert, against the background of the enlightened debates on deforestation and the presence of arid regions. According to a politically driven colonial assumption, "barren zones" are the result of traditional forms of land use. The debate on deforestation leads to a reaction against this practice (through "reforestation"), helping the development of a negative perception of landscapes without forests, i.e. arid landscapes such as the desert. As we saw in the case of the economic and patriotic associations (Baumgartner, Stuber) the watchword of the elite between $175^{\circ}$ and $185^{\circ}$ was "improvement": European style agriculture, or reforestation, must make deserts (like mountains) "flourish."

In her contribution, Barbara Orland reflects on the relationship between "geographical space," "production of knowledge," and the marginalization (or negative perception) of other forms of knowledge or traditional land use (as reflected in Gänger's and Stuber's articles). Orland's paper investigates the "birth of the Healthy Alps" and the relationship between space perception, land use and theories of a healthy lifestyle through a case study: the Swiss whey cures. During the second half of the 18th century, whey cures came to be a distinctive feature of the healthy environment of the Alps; later, in the 19th century, this cure became a means of prevention, wellbeing and sociability. In this process, good health became a benefit that could be purchased and the place where to buy the treatment became less important. In this way, the link between landscape and health became looser and the healthy qualities of mountain milk survive mostly as symbolic capital.

The last contribution, by Chetan Singh, deals with the creation of scientific knowledge about the Himalayan region between 1784 (foundation of the Asiatick Society) and 1850. As shown in the papers by Baumgartner and Stuber, scientific societies are interested in surveying regional territories in Europe, but also in the non-European world, using a European colonial lens. Singh's article shows how the members of the Asiatick Society explored the Himalayan regions, trying to categorize people, their diseases, to map the territory, its rivers, its mountains and its resources. Accompanying this mapping of 
the Himalayan territory step by step, Singh underlines the connection between this undertaking and European explorations of other territories, the Alps or Latin America, and the influence of naturalists such as Horace-Bénédict de Saussure (1740-1799) or Alexander von Humboldt (1769-1859).

With the present collective work, we contribute to a developing social history of knowledge of territories. Our ambition is to achieve a comparative approach on a global scale, highlighting the asymmetries of knowledge and power that have influenced the exploration of territories and their human and non-human inhabitants.

\section{Acknowledgements}

This contribution is based on research funded by the Swiss National Science Foundation and carried out in the context of the projects "Kulturen der Naturforschung" (Cultures of Natural History), Projects-Nr. 144731 and 176978, at the University of Bern (2014-ongoing).

We would also like to thank Simona Cain for her proofreading work, Dominik Hünniger (series editor of "Emergence of Natural History") and Rosanna Woensdregt at Brill for their cooperation in the publication of this volume.

\section{Bibliography}

\section{Printed Sources}

Boscani Leoni, Simona, ed. "Unglaubliche Bergwunder": Johann Jakob Scheuchzer und Graubünden. Ausgewählte Briefe 1699-1707. Cultura alpina 9. Chur: Verlag Bündner Monatsblatt, 2019.

Scheuchzer, Johann Jakob. Bibliotheca scriptorum historiae naturalis omnium Terrae Regionum inservientium; historiae naturalis Helvetiae Prodromus; accessit Celeberrimi Viri Jacobi Le Long, Bibliothecarii Oratoriani de Scriptoribus historiae naturalis Galliae; collegit Johann Jakob Scheuchzer, Med. D. Math. Prof. Societ. LeopoldinoCarolinae, Regiae Angl. \& Boruss. Tiguri: Typis Henrici Bodmeri, 1716.

Scheuchzer, Johann Jakob Einladungs-Brief, zu Erforschung natürlicher Wunderen, so sich im Schweizer-Land befinden (Zurich: [D. Gessner], 1699). In "Unglaubliche Bergwunder": Johann Jakob Scheuchzer und Graubünden. Ausgewählte Briefe 16991707. Edited by Simona Boscani Leoni, 33-49. Cultura alpina 9. Chur:Verlag Bündner Monatsblatt, 2019. 


\section{Literature}

Ash, Mitchell G. "Wissens- und Wissenschaftstransfer - Einführende Bemerkungen." Berichte zur Wissenschaftsgeschichte 29, no. 3 (2006): 181-89.

Andersson Burnett, Linda "An Eighteenth-Century Ecology of Knowledge: Patronage and Natural History," Culture Unbound - Journal of Current Cultural Research 6 (2014): 1275-1297.

Anthony, Patrick, ed. Working at the Margins: Labor and the Politics of Participation in Natural History, 1700-1830. Special Issue of: Berichte zur Wissenschaftsgeschichte 44, no. 2 (2021).

Barrera-Osorio, Antonio. Experiencing Nature: The Spanish American Empire and the Early Scientific Revolution. Austin: University of Texas Press, 2006.

Batsaki, Yota, Sarah Burke Cahalan, and Anatole Tchikine, eds. The Botany of Empire in the Long Eighteenth Century. Dumbarton Oaks Symposia and Colloquia. Washington, DC: Dumbarton Oaks Research Library and Collection, 2016.

Baumgartner, Sarah. "Das Nützliche Wissen. Akteure, Tätigkeiten, Kommunikationspraxis und Themen der Naturforschenden Gesellschaft in Zürich, 1746 bis ca. 1830." PhD diss., University of Bern, 2019.

Bertrand, Romain. 'Histoire globale, histoires connectées. Un 'tournant' historiographique?" In Le tournant global des sciences sociales, edited by Alain Caillé and Stéphane Dufoix, 44-66. Collection Bibliothèque du MAUss. Paris: Ed. La Découverte, 2013 .

Boscani Leoni, Simona, ed. Wissenschaft - Berge - Ideologien:Johann Jakob Scheuchzer (1672-1733) und die frühneuzeitliche Naturforschung - Scienza - montagna - ideologie. Johann Jakob Scheuchzer (1672-1733) e la ricerca naturalistica in epoca moderna. Basel: Schwabe, 2010.

Boscani Leoni, Simona. "Queries and Questionnaires: Collecting Local and Popular Knowledge in 17th and 18th Century Europe." In Wissenschaftsgeschichte und Geschichte des Wissens im Dialog - Connecting Science and Knowledge, edited by Kaspar von Greyerz, Silvia Flubacher, and Philipp Senn, 187-207. Göttingen: V\&R unipress, 2013.

Boscani Leoni, Simona. “The Discovery of the Alps: Between 'Science' and Exoticism.” In Exotic Switzerland? Looking Outward in the Age of Enlightenment, edited by Noémie Etienne, Claire Brizon, Chonja Lee, and Etienne Wismer, 285-97. Berlin: Diaphanes, 2020.

Bossi, Maurizio and Claudio Greppi, eds. Viaggi e scienza: le istruzioni scientifiche per $i$ viaggiatori nei secoli XVII-XIX. Gabinetto scientifico letterario G. P. Vieusseux, Studi 13. Florence: Olschki, 2005.

Boumediene, Samir. La colonisation du savoir une histoire des plantes médicinales $d u$ "Nouveau Monde" (1492-1750). Vaulx-en-Velin: Les éditions des mondes à faire, 2016. 
Bourguet, Marie-Noëlle. "Voyages lointains et mesure du monde: la projection du regard européen sur le monde (vers 1500-vers 1800)." In L'Europe des sciences et des techniques $X V^{e}-X V I I I^{e}$ siècle: un dialogue des savoirs, edited by Liliane HilairePérez, Fabien Simon, and Marie Thébaud-Sorger, 193-201. Collection "Histoire." Rennes: Presses universitaires de Rennes, 2016.

Bulinsky, Dunja. Nahbeziehungen eines europäischen Gelehrten: Johann Jakob Scheuchzer (1672-1733) und sein soziales Umfeld. Zurich: Chronos Verlag, 2020.

Capanema, Silvia, Quentin Deluermoz, Michel Molin, and Marie Redon, eds. Du transfert culturel au métissage: concepts, acteurs, pratiques. Collection "Histoire." Rennes: Presses universitaires de Rennes, 2015.

Carey, Daniel. "Inquiries, Heads, and Directions: Orienting Early Modern Travel." In Travel Narratives, the New Science and Literary Discourse: 1569-1750, edited by Judy A. Hayden, 25-52. Farnham: Ashgate, 2012.

Conrad, Sebastian. What Is Global History? Princeton, NJ: Princeton University Press, 2016.

Cooper, Alix. "The 'Possibilities of the Land': The Inventory of 'Natural Riches' in the Early Modern Territories." In Oeconomies in the Age of Newton, edited by Margaret Schabas and Neil de Marchi, 129-53. Durham: Duke University Press, 2003.

Cooper, Alix. Inventing the Indigenous: Local Knowledge and Natural History in Early Modern Europe. Cambridge, New York: Cambridge University Press, 2007.

Cooper, Alix. "Fragen ohne Antworten: Die Suche nach lokalen Informationen in der frühen Aufklärung." In Vor Google: Eine Mediengeschichte der Suchmaschine im Analogen Zeitalter, edited by Thomas Brandstetter, 73-84. Kultur- und Medientheorie. Bielefeld: transcript, 2012.

Curry, Helen A., Nicholas Jardine, James A. Secord, and Emma C. Spary, eds. Worlds of Natural History. Cambridge, New York: Cambridge University Press, 2018.

DaCosta Kaufmann, Thomas. "Interpreting Cultural Transfer and the Consequences of Markets and Exchange: Reconsidering Fumi-e." In Artistic and Cultural Exchanges Between Europe and Asia, 1400-1900: Rethinking Markets, Workshops and Collections, edited by Michael North, 136-61. London: Routledge, 2010.

Darian-Smith, Eve, and Philip C. McCarty, eds. The Global Turn: Theories, Research Designs, and Methods for Global Studies. 1st ed. Oakland: University of California Press, 2017.

Dauser, Regina, Stefan Hächler, Michael Kempe, Franz Mauelshagen, and Martin Stuber, eds. Wissen im Netz: Botanik und Pflanzentransfer in europäischen Korrespondenznetzen des 18. Jahrhunderts. Colloquia Augustana 24. Berlin: AkademieVerlag, 2008.

Dietz, Bettina. Das System der Natur: Die kollaborative Wissenskultur der Botanik im 18. Jahrhundert. Cologne: Böhlau, 2017. 
Espagne, Michel. "Der theoretische Stand der Kulturtransferforschung." In Kulturtransfer: Kulturelle Praxis im 16. Jahrhundert, edited by Wolfgang Schmale, 63-76. Wiener Schriften zur Geschichte der Neuzeit 2. Innsbruck: Studien-Verlag, 2003.

Fan, Fa-ti. "The Global Turn in the History of Science." East Asian Science, Technology and Society: An International Journal 6 (2012): 249-58.

Findlen, Paula. "Anatomy Theaters, Botanical Gardens, and Natural History Collections." In The Cambridge History of Science: Early Modern Science, edited by Katharine Park and Lorraine Daston, 272-89. Cambridge History of Science 3. Cambridge, New York: Cambridge University Press, 2006.

Gantet, Claire, and Markus Meumann, eds. Les échanges savants franco-allemands au

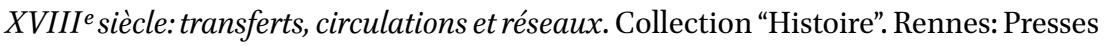
universitaires de Rennes, 2019.

Graber, Rolf. Bürgerliche Öffentlichkeit und spätabsolutistischer Staat: Sozietätenbewegung und Konfliktkonjunktur in Zürich 1746-1780. Zurich: Chronos, 1993.

Jacob, Christian, ed. Lieux de savoir: espaces et communautés. Paris: Albin Michel, 2007. Jardine, Nicholas, and Emma Spary. "Worlds of History." In Worlds of Natural History, edited by Curry, Jardine, Secord, Spary, 3-14.

Jardine, Nicholas, Emma C. Spary, and James A. Secord, eds. Cultures of Natural History. Cambridge, New York: Cambridge University Press, 1996.

Kempe, Michael. Wissenschaft, Theologie, Aufklärung:Johann Jakob Scheuchzer (16721733) und die Sintfluttheorie. Frühneuzeit-Forschungen 10. Epfendorf: bibliotheca academica Verlag, 2003.

Knittel, Meike. "Netzwerke der Botanik. Johannes Gessner (1709-179o) und die Botanische Forschung im 18. Jahrhundert." PhD diss., University of Bern, 2018.

Koerner, Lisbet. Linnaeus: Nature and Nation. 3. ed. Cambridge, MA: Harvard University Press, 2001.

Kury, Lorelai. "Les instructions de voyage dans les expéditions scientifiques françaises (1750-1830)," Revue d'histoire des sciences 51, no. 1 (1998): 65-92.

Kury, Lorelai. Histoire naturelle et voyages scientifiques (1780-1830). Paris: L'Harmattan, 2001.

Latour, Bruno. “Comment redistribuer le Grand Partage?” Revue de synthèse 110 (1983): 202-36.

Latour, Bruno. "Visualisation and Cognition: Drawing Things Together." In Knowledge and Society: Studies in the Sociology of Culture Past and Present. Vol. 6, edited by Henrika Kuklick and Elizabeth Long, 1-40. Greenwich CT, London: Jai Press, 1986.

Latour, Bruno. Science in Action: How to Follow Scientists and Engineers Through Society. Cambridge, MA: Harvard University Press, 1987.

Leu, Urs B., ed. Natura Sacra: Der Frühaufklärer Johann Jakob Scheuchzer (1672-1733). Zug: Achius Verlag, 2012. 
MacGregor, Arthur, ed. Naturalists in the Field: Collecting, Recording and Preserving the Natural World from the Fifteenth to the Twenty-First Century. Emergence of Natural History, vol. 2. Leiden: Brill, 2018.

Manning, Patrick, and Daniel Rood. Global Scientific Practice in an Age of Revolutions, 1750-1850. Pittsburgh: University of Pittsburgh Press, 2016.

Mitchell, W. J. Thomas. "Introduction." In Landscape and Power, 2nd ed., edited by W. J. Thomas Mitchell. Chicago, London: The University of Chicago Press, 2002: 1-5. Mommertz, Monika. "Heroization in Science, Scholarship, and Knowledge-Production: The Intellectual Hero in Transdisciplinary and Trans-Epochal Perspective." Helden. Heroes. Héros. Special Issue 4 (2018): 3-12.

Morus, Iwan R. "Invisible Technicians, Instrument-Makers and Artisans." In $A$ Companion to the History of Science, edited by Bernard V. Lightman, 97-110. New York: John Wiley and Sons, 2016.

Ogilvie, Brian W. The Science of Describing. Natural History in Renaissance Europe. Chicago, London: The University of Chicago Press, 2006.

Ortmayr, Norbert. "Kulturpflanzentransfers 1492-19oo." Historische Sozialkunde: Geschichte, Fachdidaktik, politische Bildung 1 (2002): 22-30.

Pomeranz, Kenneth. The Great Divergence: China, Europe, and the Making of the Modern World Economy. The Princeton Economic History of the Western World. Princeton NJ: Princeton University Press, 2000.

Popplow, Marcus. "Die Ökonomische Aufklärung als Innovationskultur des 18. Jahrhunderts zur optimierten Nutzung natürlicher Ressourcen." In Landschaften agrarisch-ökonomischen Wissens: Strategien innovativer Ressourcennutzung in Zeitschriften und Sozietäten des 18. Jahrhunderts, edited by Marcus Popplow, 2-48. Cottbuser Studien zur Geschichte von Technik, Arbeit und Umwelt 30. Münster: Waxmann, 2010.

Pugliano, Valentina. "Natural History in the Apothecary's Shop." In Worlds of Natural History, edited by Curry, Jardine, Secord, Spary, 44-6o.

Raj, Kapil. “Quand l'Amérique a inventé la science Européenne." In Europa: une autre histoire, edited by Jakob Vogel, Thomas Serrier, and Etienne François, 1089-1102. Paris: Les Arènes, 2017.

Raj, Kapil. "Thinking Without the Scientific Revolution: Global Interactions and the Construction of Knowledge." Journal of Early Modern History 21 (2017): 1-14.

Rubiés, Joan-Pau. "Instructions for Travellers: Teaching the Eye to See," History and Anthropology 9, no. 2-3 (1996): 139-9o.

Ruppel, Sophie. Botanophilie: Mensch und Pflanze in der aufklärerisch-bürgerlichen Gesellschaft um 180o. Vienna: Böhlau, 2019.

Schär, Bernhard C. "Bauern und Hirten reconsidered: Umrisse der 'erfundenen Schweiz' im imperialen Raum." In Postkoloniale Schweiz: Formen und Folgen eines 
Kolonialismus ohne Kolonien, edited by Patricia Purtschert, 315-31. Postcolonial Studies 10. Bielefeld: transcript, 2012.

Schär, Bernhard C. "On the Tropical Origins of the Alps. Science and the Colonial Imagination of Switzerland, 1700-1900." In Colonial Switzerland: Rethinking Colonialism from the Margins, edited by Patricia Purtschert and Harald Fischer-Tiné, 29-49. Cambridge Imperial and Post-Colonial Studies Series. Basingstoke: Palgrave Macmillan, 2015 .

Schiebinger, Londa, and Claudia Swan, eds. Colonial Botany: Science, Commerce, and Politics in the Early Modern World. Philadelphia: University of Pennsylvania Press, 2005 .

Schiebinger, Londa. The Mind Has No Sex? Women in the Origins of Modern Science. Cambridge, MA: Harvard University Press, 1989.

Schmale, Wolfgang, ed. Kulturtransfer: Kulturelle Praxis im 16. Jahrhundert. Wiener Schriften zur Geschichte der Neuzeit 2. Innsbruck: Studien-Verlag, 2003.

Shapin, Steven. “The Invisible Technician.” American Scientist 77, no. 6 (1989): 554-63.

Sigrist, René, Eric Widmer, and Wladimir Berelowitsch, "Les lieux des sciences dans l'Europe moderne." In Lieux d'Europe: mythes et limites, edited by Stella Ghervas and François Rosset, 45-64. Paris: Ed. de la Maison des sciences de l'homme, 2008.

Speich, Daniel. "Mountains Made in Switzerland: Facts and Concerns in NineteenthCentury Cartography." Science in Context 22, no. 3 (2009): 387-408.

Stagl, Justin. A History of Curiosity: The Theory of Travel 1550-1800. Studies in Anthropology and History (Chur: Harwood Academic Publishers, 1995).

Stapelbroek, Koen, and Jani Marjanen, eds. The Rise of Economic Societies in the Eighteenth Century: Patriotic Reform in Europe and North America. Basingstoke: Palgrave Macmillan, 2012. 